\title{
Breaking blades: Experimental programme on intentional fracturing systems of lithic tools
}

\author{
M. Cristina López-Rodríguez ${ }^{1}$, Ignacio Martín-Lerma ${ }^{2}$, \\ Juan A. Marín de Espinosa Sánchez ${ }^{3}$, Carmen Gutiérrez Sáez ${ }^{1}$
}

1. Universidad Autónoma de Madrid. Departamento de Prehistoria y Arqueología, Cantoblanco. Madrid, Spain. Email: López-Rodríguez: mariacristina.lopez@predoc.uam.es; Gutiérrez Sáez: carmen.gutierrez@uam.es

2. Departamento de Prehistoria, Arqueología, Historia Antigua, Historia Medieval y CC.TT. Historiográficas, Universidad de Murcia. Murcia, Spain. Email: ignacio.martin@um.es

3. Sílex. Arqueología y difusión del Patrimonio S.L., Murcia, Spain. Email: info@tallarsilex.com

\begin{abstract}
:
This research represents a first approach to the characterization of blade fractures produced intentionally using various techniques, according to an experimental protocol. The objective is to establish a reference base of marks which serve to define the fractures documented in the archaeological record.

The fractured blade being a very common element in different sites throughout in the Iberian Peninsula during the Neolithic and Chalcolithic Ages. In fact, from the Late Neolithic a new concept applied to the creation of lithic tools arose, involving the fracturing of blades through the improvement of fracturing techniques. In addition, a preference for obtaining the mesial fragments of the blades or those which have more regular measurements can be observed. This type of lithic instrument represents high percentages of all the retouched material, and may possess only one fractured end or, more commonly, both, bi-fractured.

With the archaeological evidence, we decided to carry out an experiment to define and classify the marks that result during the intentional fracturing of laminar fragments, contemplating different variables. We used three types of techniques for fracturing blades: flex, direct percussion and indirect percussion, and we used different types of hammer, made of stone, antler and copper.

For the results, we have standardized the descriptions of different parts of the fracture distinguishing: types of fracture, fracture planes, fracture marks and macrowear. However, we should point out that this experimentation is the beginning of a line of research that, over time, must integrate a wider experimental base which also considers the other mentioned causes of fracture, as well as the functional objective of these tools.

The preliminary study through this experimentation has made it possible to define and describe the types of fractures resulting from the use of different blade fracturing methods. We also have described the main types of fracture marks generated from each fracturing technique.
\end{abstract}

Keywords: lithic industry; intentional breaking; fracture marks; experimental archaeology; blade technology

Published by the School of History, Classics and Archaeology, University of Edinburgh ISSN: 2055-0472. URL: http://journals.ed.ac.uk/lithicstudies/

This work is licensed under a Creative Commons Attribution 2.5 UK: Scotland License. 


\section{Introduction}

The approach to this issue arosen during the study of the lithic industry in Humanejos (Madrid, Spain). This site has a deposit with chronologies that range from the Chalcolithic period to the Bronze Age (Flores Fernández 2011; Flores Fernández \& Garrido Pena 2012).

An initial study dealt with the selected material during excavation, amounting to 357 retouched pieces of which 276 are blades (212 blades +31 bladelets). Among these 212 blades, the mesial elements represent $50 \%$ of the total (111 fragments), followed by 33\% of meso-proximal fragments and 14\% meso-distal, as we see in Figure 1. (For examples, see Figure 2.) Obviously, until the completion of the study, other retouched elements may appear, and thus change of these frequencies.



Figure 1. Histogram of the 212 blade fragments from Humanejos that were studied.

The abundance of blade fragments, in particular mesial pieces, has been reviewed previously by other authors in some sites with chronologies ranging from the Neolithic to the Chalcolithic (Armendariz Martija and Irigaray Soto 1992; Fortea Pérez et al. 1985; Gutiérrez Sáez 1998). This type of lithic instrument represents more than $50 \%$ of all the retouched material, and may possess only one fractured end or, more commonly, both, i.e. bifractured. In general, for these authors, the goal of these intentional fractures was to obtain smaller modules and standardized formats to be used as elements in series, without advancing further in this interpretation.

Examples of this trend are fractured blades from deposits at Cova de Ors (Beniarrés, Alicante, Spain) and Cova de la Sarsa (Bocairent, Valencia, Spain), classical sites of the early Levantine Neolithic, studied by Fortea Pérez et al. (1985). These authors highlight a "clear and systematic shortening of blades through voluntary fractures, usually due to bending or percussion. This technical solution reveals a stereotyped production of blank fragments, in many cases ready to be used directly, without secondary modifications" (Fortea Pérez et al. 1985: 9). 

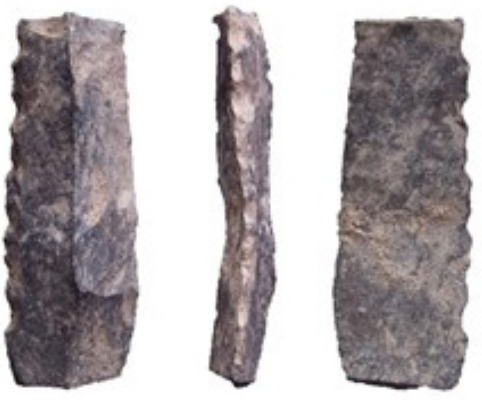

1

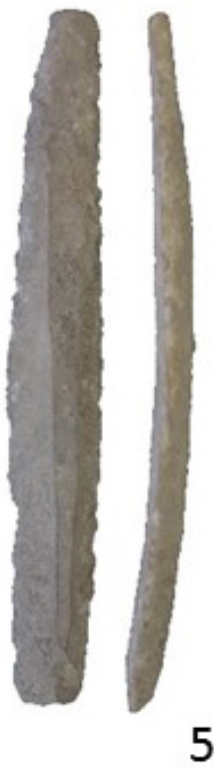

5

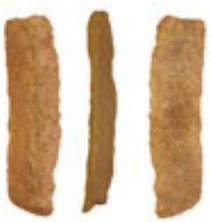

10
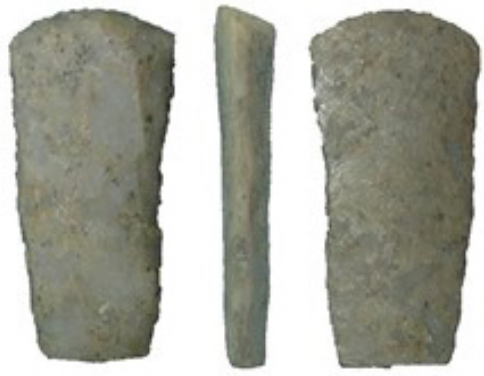

14

11
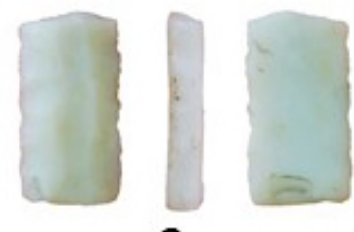

2
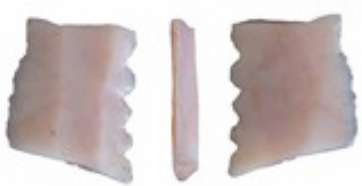

4
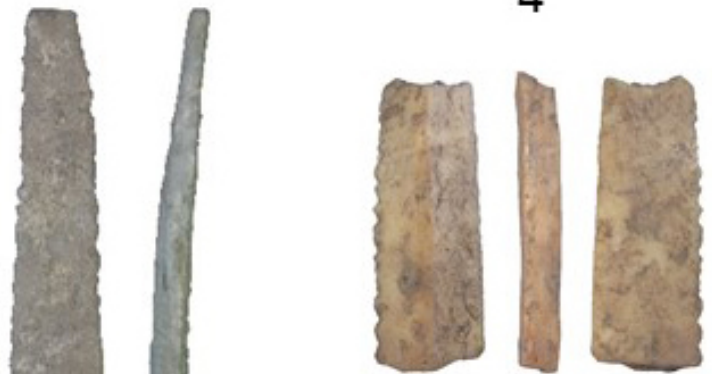

6

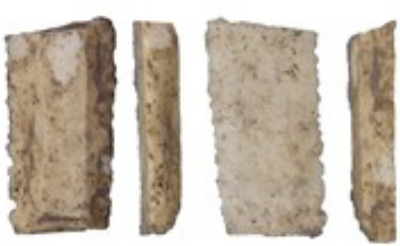

8
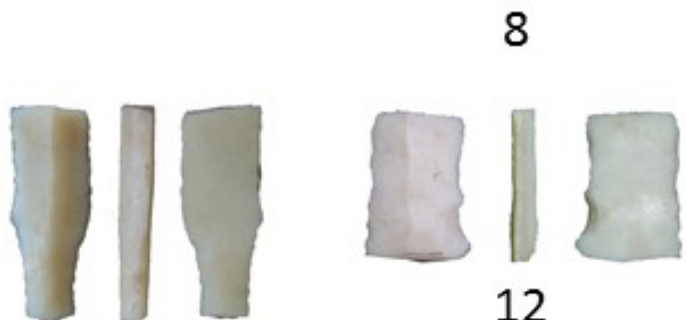

12
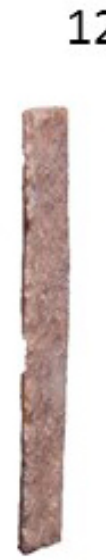

15


3


7
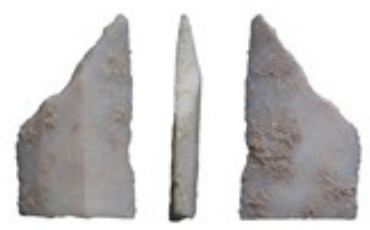

9
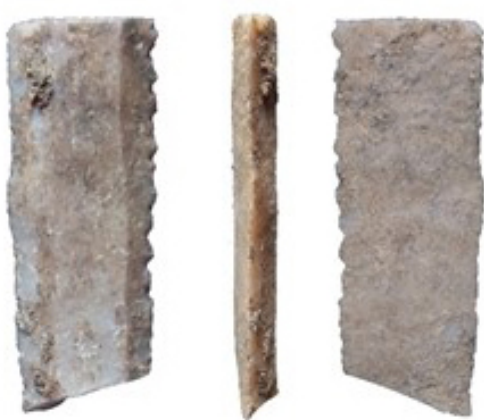

13
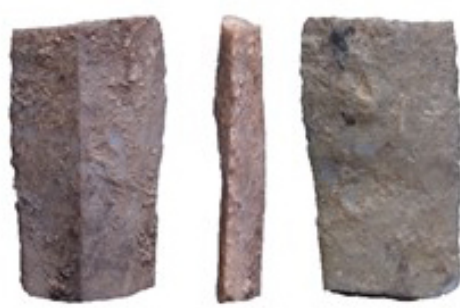

16

Figure 2. Examples of fragmented blades from the site of Humanejos. 1, 2, 4, 6, 8, 9 and 11-16: mesial fragments of bi-fractured blades; 3 and 10: meso-proximal fragment; 5: fractured blade on the distal end; 7: meso-distal fragment. 
This preference is also documented in later contexts. We must emphasize the research of Armendáriz Martija and Irigaray Soto (1992) and Gutierrez Sáez (1998) regarding Chalcolithic industries from different areas of the Iberian Peninsula. In the first case, the authors even propose a new element called "trimmed blade element" (Ehr) due to its abundance in the archaeological record, suggesting that these elements were fractured by bending stress or percussion, especially referring to those elements that present abrupt retouching and clipping at the ends. This procedure removes the different marks of the fracturing and obtains, at the same time, more regular silhouettes.

The second example comes from the study of the site of Llanete of the Moros (Llanete de los Moros) in Montoro (Córdoba, Spain) (Gutierrez Sáez 1998). It states that the abundance of mesial elements seems to indicate the existence of a change in the concept of the tool between the Final Neolithic and initial Chalcolithic period. This change would be the substitution of lithic tools which are composed of a single element with others which use compound elements composed of several standardized lithic elements. Although, the adaptation of these elements to a handle, either as individual elements or in series, requires the elimination of irregularities such as bulbs, distal curvatures, and others (see Figure 3).

On the other hand, the standardization of blanks has been proposed as a result of the spread of agriculture during the Chalcolithic (Ramos Muñoz 1989: 137-138), with exclusive reference to sickle blade segments. Furthermore, Ramos Muñoz emphasizes the high degree of fracturing presented in the blades from the site of Valencina de la Concepción (Sevilla, Spain), where 88.96\% of the lithic industry is fractured (Ramos Muñoz 1992: 46).

In general, for the aforementioned chronologies, there is a tendency towards favouring the use of mesial blade support with a certain degree of standardized production. Their advantage is that they are morphologically regular elements, and therefore are interchangeable and easy to replace in case of breakage (Sáez Gutiérrez 1998). This format includes blanks no-retouched and, in some special cases, presents different types of retouch techniques.

The fact that most of these archaeological blades are fractured, on one or both ends, has prevented an equally thorough research regarding the causes of these fractures. Theses may have accidentally originated during the process of knapping, by dropping or trampling, due to taphonomic causes, or may also have been produced intentionally.

In the first case, the accidental breakage during knapping (either while producing the initial lithic tool or during the retouching process) is a phenomenon well-known among specialists of lithic technology given a characterization of the marks associated with the broken fragments (Gallet 1998; Gallet \& Texier 1991; Inizian et al. 1992; Pelegrin 2000; 2007; 2012). Trampling has been studied specifically by other researchers (Hartwell \& Weitzel 2007; Weitzel et al. 2014).

Intentional fracturing has been addressed by experimenting on different types of blanks and raw materials (Aschero 1975; Chapman 2000; Johnson 1979; Weitzel 2009; 2010; 2011). These works have provided an extensive collection of descriptions of the different types of fractures and their marks, but the variation of marks is loosely related to the techniques employed.

The intention of this paper is to focus exclusively on the study of intentional fractures in blades made of flint. With the archaeological evidence, we decided to carry out an experiment to define and classify the marks that result during the intentional fracturing of laminar fragments, contemplating different variables. However, we should point out that this experimentation is the beginning of a line of research that, over time, must integrate a wider experimental base which also considers the other mentioned causes of fracture, as well as the functional objective of these blanks. 

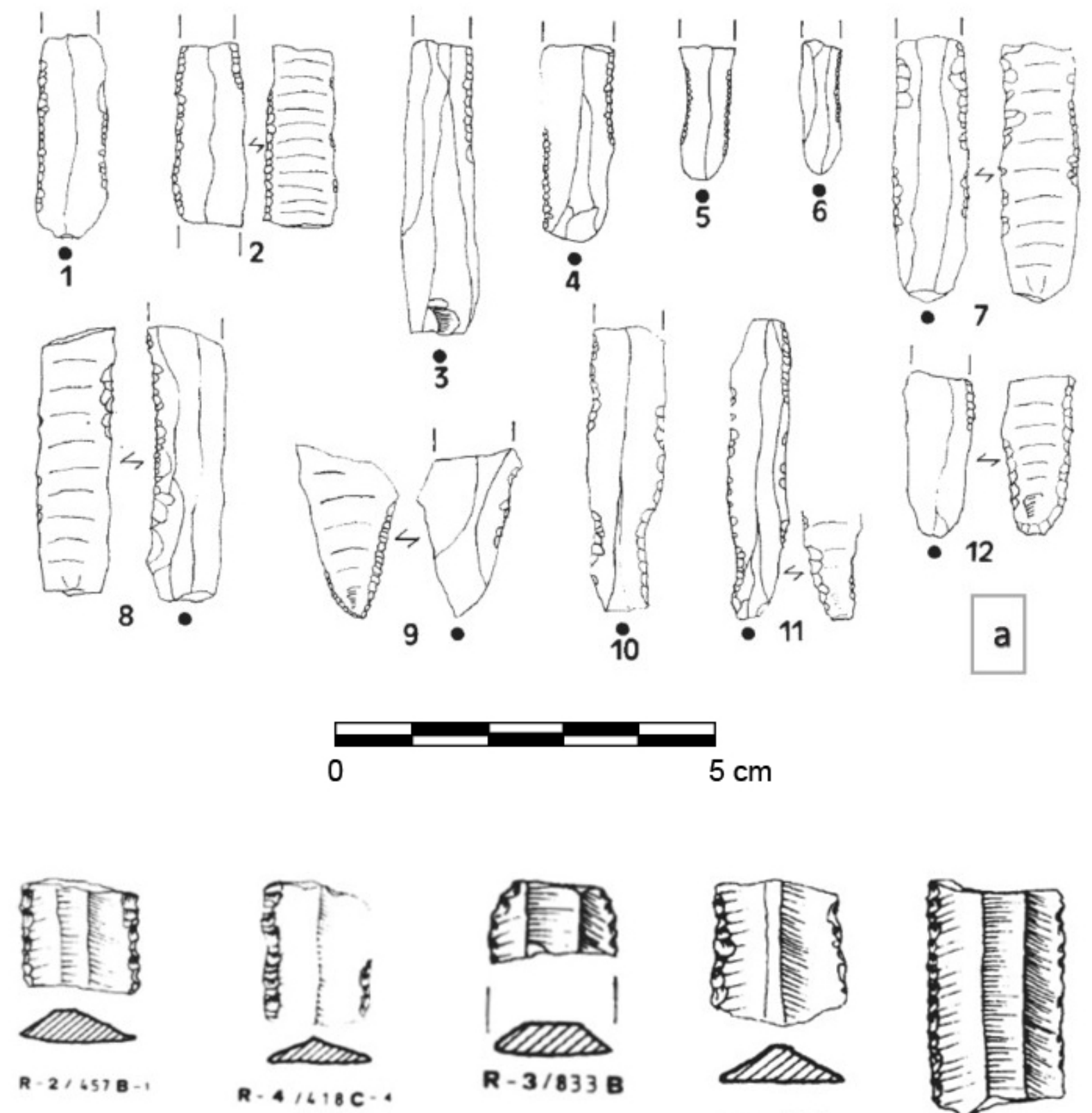

$403 \mathrm{~B}-1$
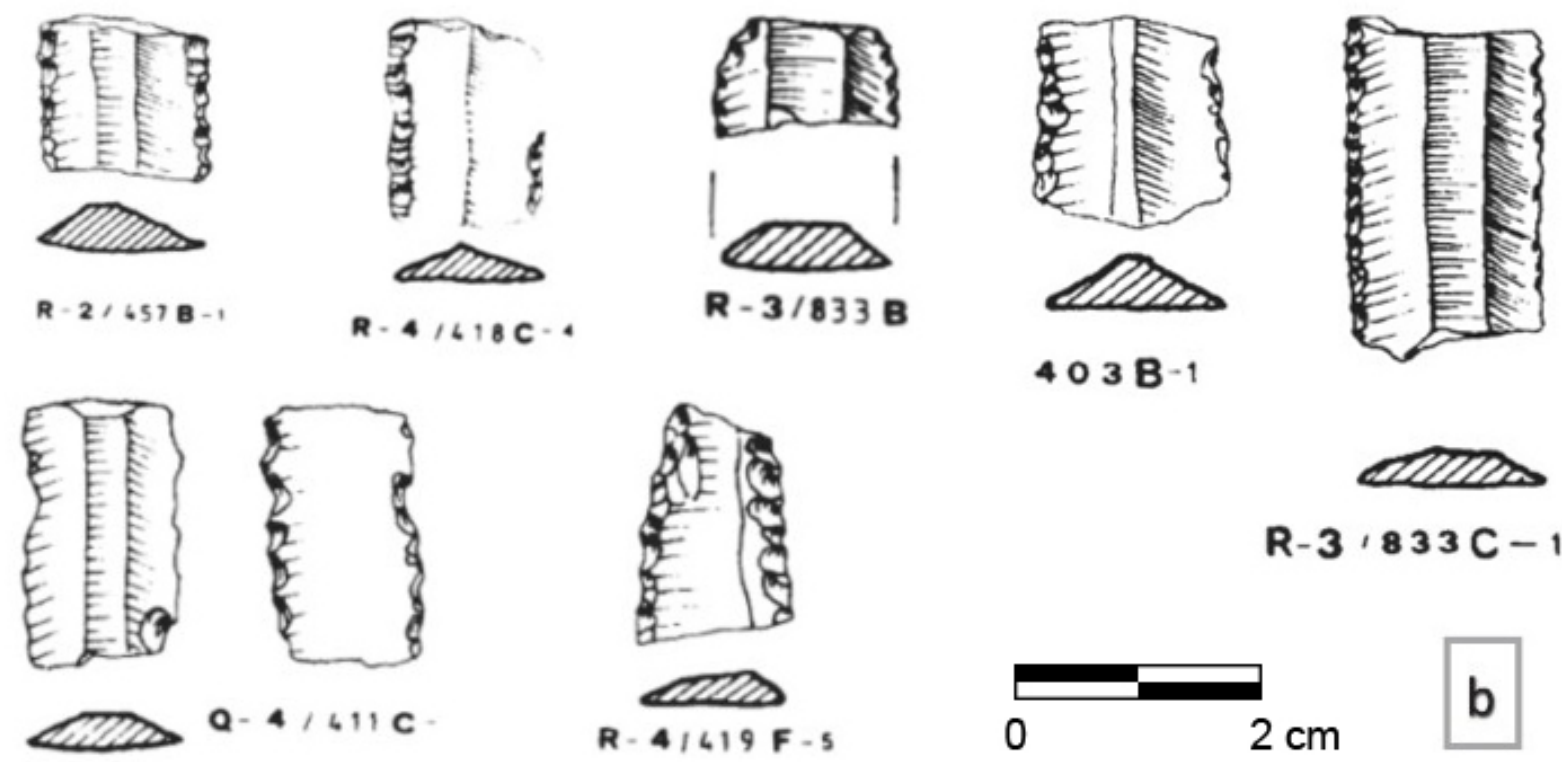

Figure3. a: flint tools from the sites of Cova de l'Or and Cova de la Sarsa, Beniarrés, Alicante (Neolithic) (Fortea et al. 1985: 10, fig. 2); b: flint tools from the site of Llanete de los Moros, Montoro, Córdoba (Chalcolithic) (Gutiérrez Sáez 1998: 196, fig.: 2, 201, fig. 4). 


\section{Variables}

At this time, we have focused on the two most common fracturing techniques mentioned in the bibliographic collection: flexing-bending and percussion.

For bending fractures, a single subvariable has been established, this being the face of the blade, either dorsal or ventral, on which the force is exerted.

For fracturing by percussion, we have also used the subvariable of the face of the blade on which the impact occurs, but adding other specific knapping processes. These are the following: the types of percussion, either direct or indirect; the type of hammer, hard (stone) or soft (antler), for the direct percussion; and the type of chisel, hard (copper) or soft (antler), for indirect percussion. Finally, the last subvariable is how the blade is placed on the anvil, being either fully supported or semi-supported, as well as the hardness of the supporting surface, distinguishing between hard, with blade supported on a stone anvil, or soft, covering the surface of the anvil with leather.

The set of blades that make up the sample were produced by various techniques with the aim of obtaining different thicknesses that could be fractured by percussion or manual bending.

In total, 94 samples were used in the study (see Table 1).

\section{Results}

The characteristics of the fractures obtained during the process of experimentation are described below. Classifications made by different authors for different typologies and raw materials (Aschero 1975; Jennings 2011; Lintz \& Dockall 2002; Miller 2006; Weitzel 2010; 2012) and that have focused on the qualitative description of the features generated by means of experimentation were taken into account (see Figure 4).

\subsection{Direct and indirect fractures}

One type of accident that has been documented is that when trying to break a blade in a particular area, it breaks in two places at the same time. In this study, "direct fractures" are consider to be those which occur in the area of the blade where the force has been applied, while "indirect fractures" originate in a different area from the point where force was applied (Johnson 1979).

Indirect fractures usually appear in blades with a slight distal curvature or blades that become thinner towards one of the ends. In this sense, we have found that the place where indirect fractures appear depends mainly on the regularity of the width and the thickness of the blade. If the contrast of thickness between the impact area and ends is very pronounced, the possibility for generating indirect fractures at the ends is higher. In this study's experiments, $15.95 \%$ of the blades generated an indirect fracture. These were located mainly in the distal area (66.67\%) (see Figure 5).

The technique used for fracturing was essential in the formation of indirect fractures. Flexing did not produce any indirect fractures, and therefore, all are associated with the use of percussion. With the latter, there have been more cases of this type of fracture with indirect percussion (62.5\%) than with direct percussion (29.4\%). Hardness of the hammer does not seem to be significant in this aspect. 
Table 1. Variables used during the experimentation.

\begin{tabular}{|c|c|c|c|c|c|c|}
\hline $\begin{array}{l}\text { Raw } \\
\text { material }\end{array}$ & $\begin{array}{l}\text { Percussion } \\
\text { surface }\end{array}$ & Technique & Percussion & Hammer & $\begin{array}{l}\text { Way of } \\
\text { support }\end{array}$ & $\begin{array}{l}\text { Hardness of } \\
\text { the anvil }\end{array}$ \\
\hline \multirow[t]{22}{*}{ Flint } & Dorsal & Flex & & & & \\
\hline & & Percussion & Direct & Hard & Complete & $\begin{array}{l}\text { Hard } \\
\text { Soft }\end{array}$ \\
\hline & & & & & Semi & $\begin{array}{l}\text { Hard } \\
\text { Soft }\end{array}$ \\
\hline & & & & Soft & Complete & $\begin{array}{l}\text { Hard } \\
\text { Soft }\end{array}$ \\
\hline & & & & & Semi & $\begin{array}{l}\text { Hard } \\
\text { Soft }\end{array}$ \\
\hline & & & Indirect & Hard & Complete & $\begin{array}{l}\text { Hard } \\
\text { Soft }\end{array}$ \\
\hline & & & & & Semi & Hard \\
\hline & & & & & & Soft \\
\hline & & & & Soft & Complete & $\begin{array}{l}\text { Hard } \\
\text { Soft }\end{array}$ \\
\hline & & & & & Semi & $\begin{array}{l}\text { Hard } \\
\text { Soft }\end{array}$ \\
\hline & Ventral & Flex & & & & \\
\hline & & Percussion & Direct & Hard & Complete & Hard \\
\hline & & & & & & Soft \\
\hline & & & & & Semi & $\begin{array}{l}\text { Hard } \\
\text { Soft }\end{array}$ \\
\hline & & & & & Complete & $\begin{array}{l}\text { Hard } \\
\text { Soft }\end{array}$ \\
\hline & & & & & Semi & $\begin{array}{l}\text { Hard } \\
\text { Soft }\end{array}$ \\
\hline & & & & Soft & Complete & $\begin{array}{l}\text { Hard } \\
\text { Soft }\end{array}$ \\
\hline & & & & & Semi & $\begin{array}{l}\text { Hard } \\
\text { Soft }\end{array}$ \\
\hline & & & Indirect & Hard & Complete & $\begin{array}{l}\text { Hard } \\
\text { Soft }\end{array}$ \\
\hline & & & & & Semi & $\begin{array}{l}\text { Hard } \\
\text { Soft }\end{array}$ \\
\hline & & & & Soft & Complete & $\begin{array}{l}\text { Hard } \\
\text { Soft }\end{array}$ \\
\hline & & & & & Semi & $\begin{array}{l}\text { Hard } \\
\text { Soft }\end{array}$ \\
\hline
\end{tabular}



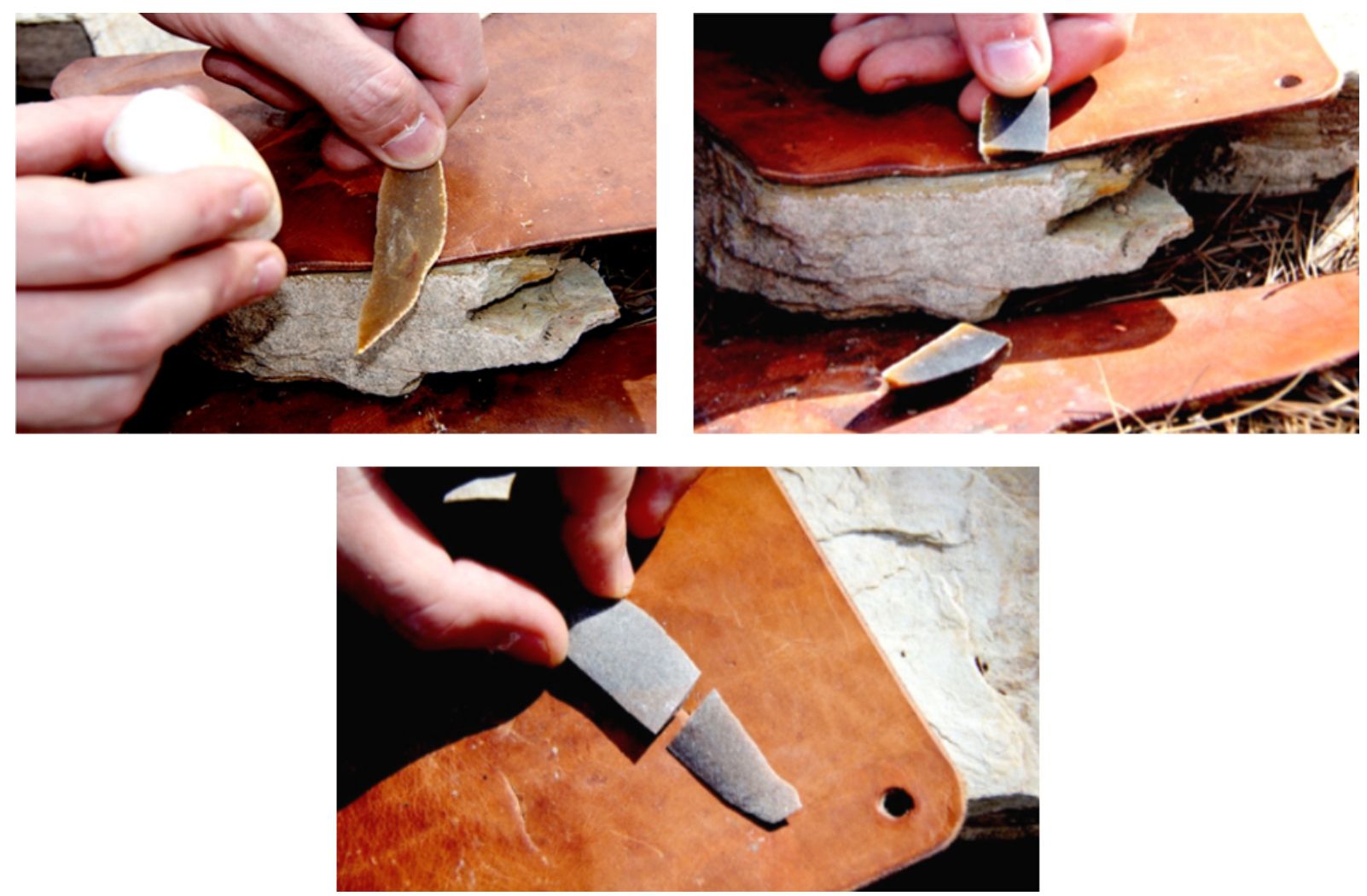

Figure 4. Images taken during the experimentation.

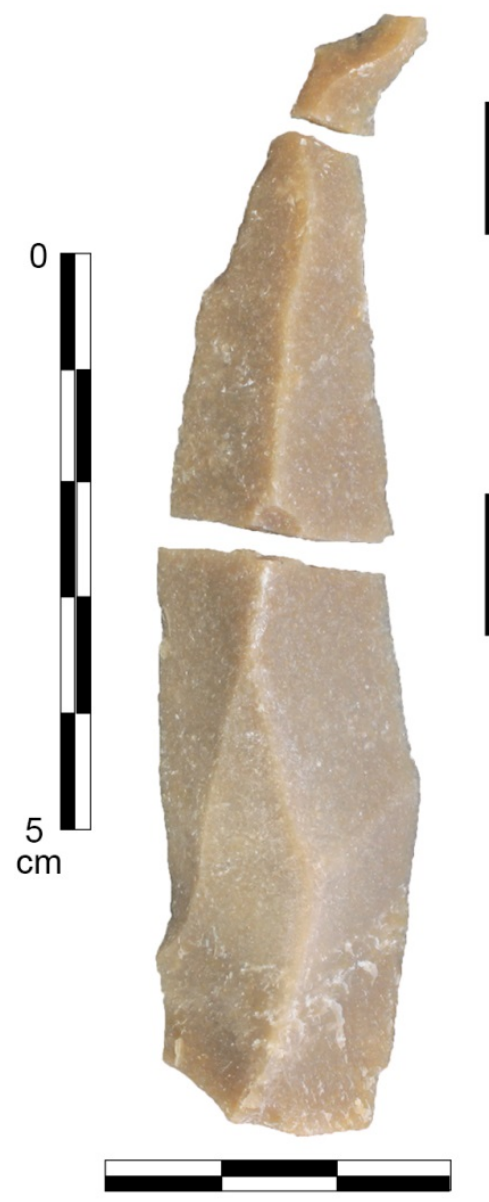

\section{Indirect fracture}

\section{Direct fracture}

\section{Location of the indirect fractures}

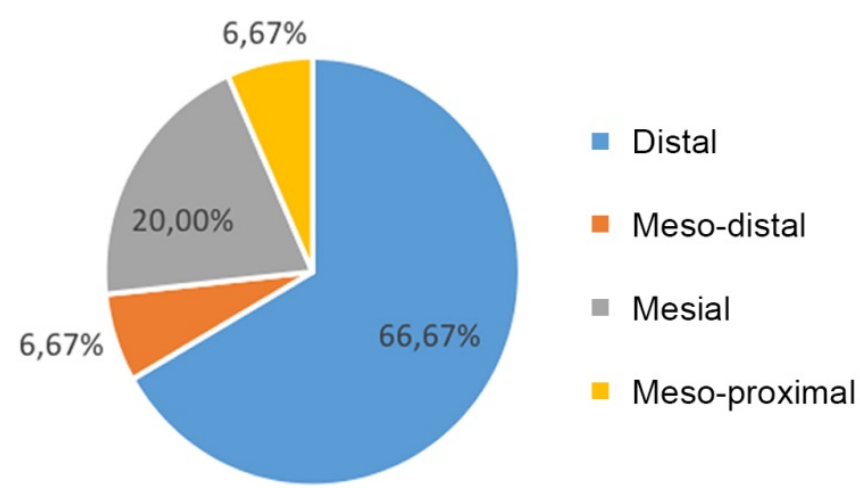

Figure 5. Distinction between a direct fracture in the mesial area and an indirect fracture in the distal area. Inset: Chart showing the percentages of the areas where indirect fractures are present. 
The face where the impact is produced generates the same number of indirect fractures regardless of the side ( 8 for blades with impact on the dorsal face and 7 with impact on the ventral side). However, this variable is closely related to the means of support. If the impact occurs on the dorsal face and the blade is fully supported on the surface of the anvil, the indirect fracturing index is greater than when semi-supported. On the contrary, if the impact occurs on the ventral surface, indirect fractures were obtained on 2 fully supported blades, while 5 were obtained on semi supported blades (Table 2). Hardness of the support area has not proven to be significant (see Table 2).

Table 2. Indirect fractures generated in relation to the face of impact and mode of support of the blade on the anvil.

\begin{tabular}{lcc}
\hline & $\begin{array}{c}\text { Completely supported } \\
\text { Count (\%) }\end{array}$ & $\begin{array}{c}\text { Semi supported } \\
\text { Count (\%) }\end{array}$ \\
\hline Impact on dorsal face & $6(75.00)$ & $2(25.00)$ \\
Impact on ventral face & $2(28.57)$ & $5(71.43)$ \\
\hline
\end{tabular}

\subsection{Types of fracture: Simple, radial and fracture with cone}

Simple fractures occur when the blade is divided into two segments leaving a smooth fracture surface.

In historiography, simple fractures could be equated to "simple transverse fracture types", documented in bifacial pieces. It has been defined as "a single flattened, untwisted, mostly unlipped and featureless fracture surface oriented perpendicular to the tool edge/long axis. No direct association of the fracture exists with a flake scar and no direct link between fracture propagation and pressure or percussion flaking" (Lintz \& Dockall 2002: 19). However, in blades this fracture can occur transversely or slightly oblique to the longitudinal axis of the blade and is not only obtained by flexing, but also by percussion.

On the contrary, in the radial fracture three or more independent fragments are broken off. Of these there are two different types:

- The so-called "mid-roll" (Deller \& Ellis 2001: 271; Weitzel 2011: 40) has been defined as a type of intentional fracture that starts in the middle of the face of the piece and extends towards the margins (Lintz \& Dockal 2002; Frison \& Bradley 1980: 44).

- The second type, 'fracture with cone', presents a medial wedge, located in the centre of the piece, which detaches with the shape of a "Hertzian cone". This type has been considered a result of "an intentional impact on the surface of the instrument that gives off a real cone" (Weitzel \& Colombo 2006: 25) (see Figure 6).

\subsection{Types of direct fractures}

Simple fractures have been documented with all of the techniques of fracturing and are, in fact, the only ones that appear during flexing or bending. As can be seen in Table 3.A, radial fractures were exclusively generated with the technique of percussion, linking this type of fracture directly to the technique.

Distinguishing the type of percussion, direct percussion produces more simple fractures (88.24\%) than radial ones (11.76\%), while indirect percussion produces the same percentage of both. Furthermore, cone fractures are associated only with indirect percussion (see Table 3).

The hardness of the hammer did not produce significant differences in the formation of any specific type of fracture. This fact has also been noted by other authors (Weitzel 2011: $50)$. 


\section{Types of fracture}
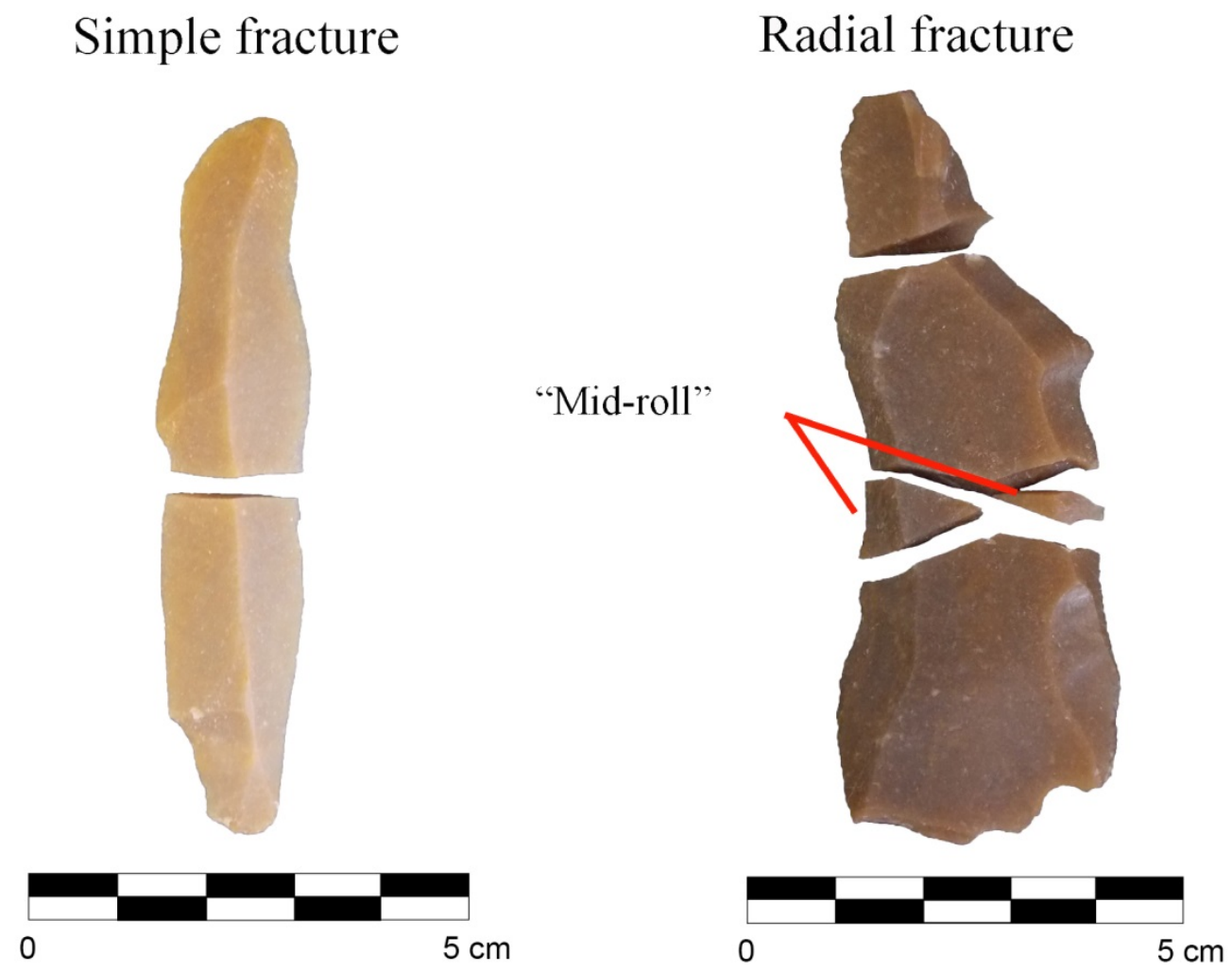

Radial fracture with cone



Figure 6. Examples of fracture types. 
Table 3. Direct fractures. A: relation between the type of fracture, the technique used and the hardness of the hammer. B: relation between the type of fracture and mode of support of the blade on the anvil and the hardness of the surface of the anvil. C: relation between the type of fracture and the face of impact.

\begin{tabular}{|c|c|c|c|c|}
\hline & & $\begin{array}{l}\text { Simple } \\
\text { fracture }\end{array}$ & $\begin{array}{l}\text { Radial } \\
\text { fracture }\end{array}$ & $\begin{array}{l}\text { Fracture } \\
\text { with cone }\end{array}$ \\
\hline & & Count (\%) & Count (\%) & Count (\%) \\
\hline \multirow[t]{2}{*}{ A. Technique } & Hammer & & & \\
\hline & Flex & $14(100.00)$ & 0 & 0 \\
\hline \multirow[t]{3}{*}{ Direct percussion } & Stone & $8(88.89)$ & $1(11.11)$ & 0 \\
\hline & Antler & $7(87.50)$ & $1(12.50)$ & 0 \\
\hline & Subtotal: & $15(88.24)$ & $2(11.76)$ & 0 \\
\hline \multirow[t]{4}{*}{ Indirect percussion } & Copper & $4(50.00)$ & $2(25.00)$ & $2(25.00)$ \\
\hline & Antler & $2(25.00)$ & $4(50.00)$ & $2(25.00)$ \\
\hline & Subtotal & $6(37.50)$ & $6(37.50)$ & $4(25.00)$ \\
\hline & Total: & 35 (74.47) & $8(17.02)$ & $4(8.51)$ \\
\hline \multirow[t]{2}{*}{ B. Way of support } & Hardness of the anvil & & & \\
\hline & Flex & $14(100.00)$ & 0 & 0 \\
\hline \multirow[t]{3}{*}{ Complete } & Hard & $5(62.50)$ & $3(37.50)$ & 0 \\
\hline & Soft & $4(50.00)$ & $2(25.00)$ & $2(25.00)$ \\
\hline & Subtotal: & $9(56.25)$ & $5(31.25)$ & $2(12.50)$ \\
\hline \multirow[t]{4}{*}{ Semi } & Hard & $6(66.67)$ & $2(22.22)$ & $1(11.11)$ \\
\hline & Soft & $6(75.00)$ & $1(12.50)$ & $1(12.50)$ \\
\hline & Subtotal: & $12(70.59)$ & $3(17.65)$ & $2(11.76)$ \\
\hline & Total: & 35 (74.47) & $8(17.02)$ & $4(8.51)$ \\
\hline \multicolumn{5}{|l|}{ C. Impact face } \\
\hline Dorsal & & $20(83.33)$ & $3(12.50)$ & $1(4.17)$ \\
\hline Ventral & & $15(65.22)$ & $5(21.74)$ & $3(13.04)$ \\
\hline
\end{tabular}

Table 3.B shows the relation between how the blade is supported and the hardness of the surface of the anvil, in regards to the types of fracture. The way in which the blade is placed has been shown to be significant when producing simple or radial fractures. When supported completely on the anvil face a total of 9 simple fractures (56.25) and 5 radial fractures (31.25) were obtained. However, with the blade semi-supported, percentages are more diverse with a total of 12 simple fractures (70.59\%) against 3 radial ones (17.65\%). Of the 4 fractures with cone that were obtained, 2 come from fully supported blades and another 2 from semisupported ones.

As with the hardness of the hammer, the hardness of the support area is not significant in relation to the different types of fractures.

\subsection{Types of indirect fractures}

In the case of indirect fractures, $80 \%$ are simple, while only $20 \%$ are radial. This may be due to the fact that these indirect fractures did not receive the impact directly (see Table 4). 
Table 4. Relation between the type of indirect fracture and fracturing technique employed and the hardness of the hammer.

\begin{tabular}{llccc}
\hline Technique & Hammer & $\begin{array}{c}\text { Simple } \\
\text { fracture } \\
\text { Count (\%) }\end{array}$ & $\begin{array}{c}\text { Radial } \\
\text { fracture } \\
\text { Count (\%) }\end{array}$ & $\begin{array}{c}\text { Fracture } \\
\text { with cone } \\
\text { Count (\%) }\end{array}$ \\
\hline Direct percussion & Stone & $2(100.00)$ & 0 & 0 \\
& Antler & $1(33.33)$ & $2(66.67)$ & 0 \\
& Subtotal: & $\mathbf{3 ( 6 0 . 0 0 )}$ & $\mathbf{2 ( 4 0 . 0 0 )}$ & $\mathbf{0}$ \\
\hline Indirect percussion & Copper & $3(75.00)$ & $1(25.00)$ & 0 \\
& Antler & $\mathbf{6 ( 1 0 0 . 0 0 )}$ & 0 & 0 \\
& Subtotal & $\mathbf{9 ( 9 0 . 0 0 )}$ & $\mathbf{1 ( 1 0 . 0 0 )}$ & $\mathbf{0}$ \\
\hline Total: & & $\mathbf{1 2 ( 8 0 . 0 0 )}$ & $\mathbf{3 ( 2 0 . 0 0 )}$ & $\mathbf{0}$ \\
\hline
\end{tabular}

\section{Fracture planes}

In this study, fracture planes are the section that was revealed as a result of the fracture. Two types of fracture planes have been identified in the experimentation:

- Flat plane. The development of the fracture surface is completely regular and smooth (Figure 7, left).

- Irregular plane. There are one or more edges that cut the smooth development of the surface of the fracture, resulting in a faceted or irregular plane (Figure 7, right).

\section{Types of fracture planes}

Flat plane
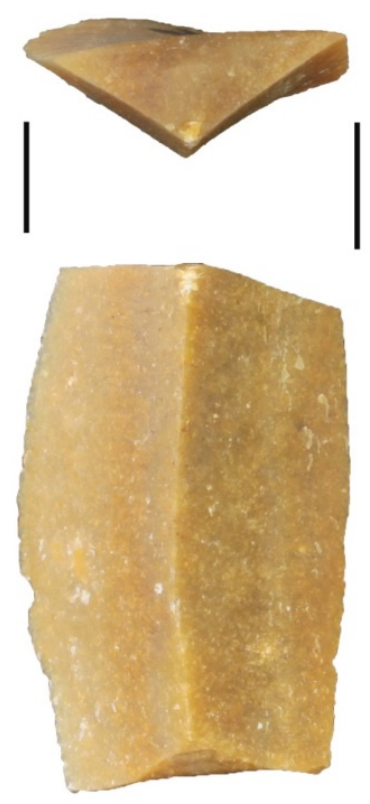

Irregular plane


Figure 7. Types of fracture planes. Left: example of flat plane. Right: example of irregular fracture plane. 
As noted in the Table 5, the flat plane is characteristic of simple fractures, while the irregular plane is mainly associated with radial and cone fractures. In the irregular planes, facets of the fracture coincide with the negatives of the mid-roll derived from the impact. This leads relates this aspect with the variable which has generated a larger amount of radial fractures - indirect percussion. These high percentages of association are important due to the fact that in the archaeological record, when intentionally fractured elements appear, they do not appear next to discarded segments. The indicative data that would allow one to determine whether it is a simple, radial or cone fracture could result from a study of the fracture plane, although it would be necessary to expand the experiment to confirm these aspects.

Table 5. Relation between types of fracture and types of bases of the fracture.

\begin{tabular}{llll}
\hline \multirow{4}{*}{ Types of fracture } & $\begin{array}{l}\text { Flat plane } \\
\text { Count (\%) }\end{array}$ & $\begin{array}{l}\text { Irregular plane } \\
\text { Count (\%) }\end{array}$ \\
\hline Direct & Simple & $59(84.29)$ & $11(15.71)$ \\
& Radial & $2(12.50)$ & $14(87.50)$ \\
& With cone & $1(12.50)$ & $7(87.50)$ \\
& Subtotal: & $\mathbf{6 2 ( 6 5 . 9 6 )}$ & $\mathbf{3 2 ( 3 4 . 0 4 )}$ \\
\hline Indirect & Simple & $17(70.83)$ & $7(29.17)$ \\
& Radial & 0 & $6(100.00)$ \\
& With cone & 0 & 0 \\
& Subtotal: & $\mathbf{1 7 ( 5 6 . 6 7 )}$ & $\mathbf{1 3 ( 4 3 . 3 3 )}$ \\
\hline & Total: & $\mathbf{7 9 ( 6 3 . 7 1 )}$ & $\mathbf{4 5 ( 3 6 . 2 9 )}$ \\
\hline
\end{tabular}

\section{Fracture marks}

Fracture marks are the marks that appear on the surface of the fracture and that classify it as a positive or a negative: a positive is produced when the stigma constitutes the high part of the profile of the fracture, and a negative side is the one that can be inserted into the positive side.

During the experimentation, the following marks were identified: tongue, sinuous section or "charnela", fall, step, bulge and without stigma.

- Tongue: This is a positive, and consists of a lump which originates on one of the surfaces (dorsal or ventral) of the fracture (Figure 8, B and C) (Bernaldo de Quiros et al. 1981). If the tongue originates on the dorsal side, it is a dorsal tongue, and if it originates on the ventral surface, it is a ventral tongue.

Tongue marks leave two types of negative marks on the opposite side:

- Fall: This consists of the rounding or smoothing of some of the faces of the fracture, either dorsal or the ventral. The fall is as long as the tongue causing it (Figure $8 \mathrm{~B}$ ). It can be compared with the "perverse fracture", considered a knapping error in experimental works with bifacial pieces characterized by having the fracture surface which is "spiralling", "twisted or kinked” or "helicoid" (Aschero 1975; Crabtree 1972; Miller 2006).

- Step: This is the second type of negative associated with the tongue (Figure 8, C). It occurs when the tongue does not end in a sharp edge, but a flat one, causing a fall that ends in a flattened base which tends to be far narrower when compared to the rest of the surface of the fracture. Although the step is frequent in all modes of fracture, they are more abundant in indirect percussion.

- Sinuous section or "Charnela": This stigma can be described as a plane whose central section is convex-concave or straight-concave in the positive side and the reverse in the negative part. On the positive side, it usually also presents a tongue which, in contrast to 
the previous one, is smaller and is preceded by a concavity which leads to an S-shaped section (Figure $8 \mathrm{D}$ ). This stigma has already been described by other authors (Weitzel 2011). If the small tongue is located on the dorsal side it is a dorsal charnela and vice versa. The negative side of a fracture with a sinuous section is a bulge.

- Bulge: This is the negative side of a fracture with a charnela. It consists of a bulge or protuberance, normally located towards one of the faces of the fracture, either dorsal or ventral, and corresponds with the concave area of its positive part (Figure $8 \mathrm{D}$ ).

- Without marks: both internal angles of the fracture are approximately $90^{\circ}$ (Figure $8 \mathrm{~A}$ ).

\begin{tabular}{|l|l|}
\hline \multicolumn{2}{|c|}{ Marks caused by the fracture } \\
\hline Positive part & Negative part \\
\hline Without marks & Without marks \\
\hline Tongue & Fall \\
\hline $\begin{array}{l}\text { Sinuous section } \\
\text { or "charnela" }\end{array}$ & Bulge \\
\hline
\end{tabular}

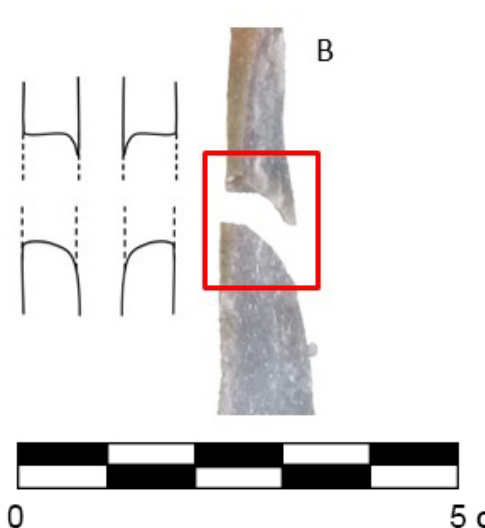

$5 \mathrm{~cm} 0$
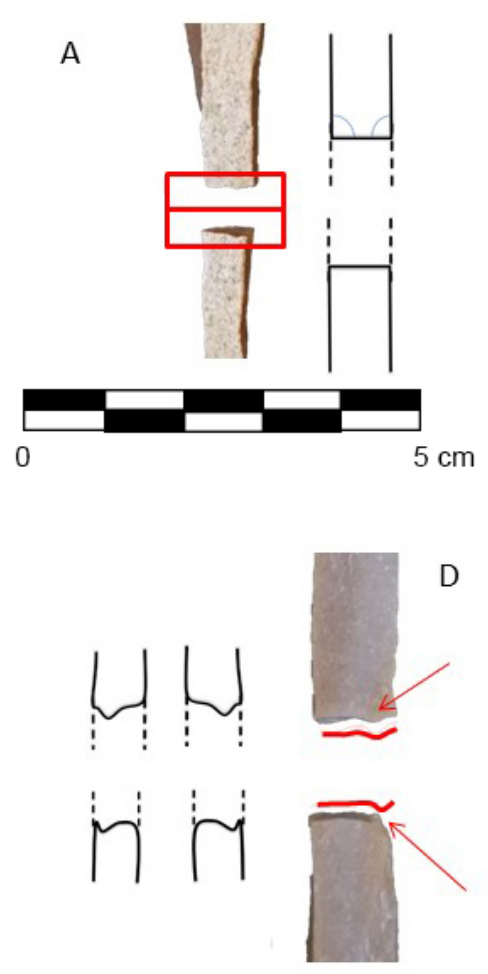

D

Figure 8. Fracture marks. A: Fracture without marks; B: Fracture with tongue and fall; C: Fracture with tongue and step; D: Fracture with sinuous section or "charnela" and bulge.

\section{Direct fracture marks}

Depending on the fracture technique that was used, one can highlight different aspects. The most represented stigma is the tongue, independently of the fragmentation method used (direct or indirect percussion or flexing), although it is especially abundant in indirect percussion. As we see in chart A of Figure 9, when the impact is on the dorsal face, occurrence percentages of dorsal and ventral tongues tend to equalize, while if the percussion is exerted on the ventral surface, ventral tongues are predominant.

The same can be said, although to a lesser extent, with the presence of charnelas or S silhouettes. Some authors have associated this stigma exclusively to the technique of flexing or bending (Bernaldo de Quirós et al. 1981: 18). However, this stigma is not only developed in this technique (10.71\%) but it is even more abundant during direct (14.71\%) and indirect percussion (12.50\%). Looking at chart B of Figure 9, the percussion on the dorsal surface produces a greater number of dorsal charnelas than ventral ones, while if percussion is exercised on the ventral surface percentages of dorsal and ventral charnelas are more similar. 

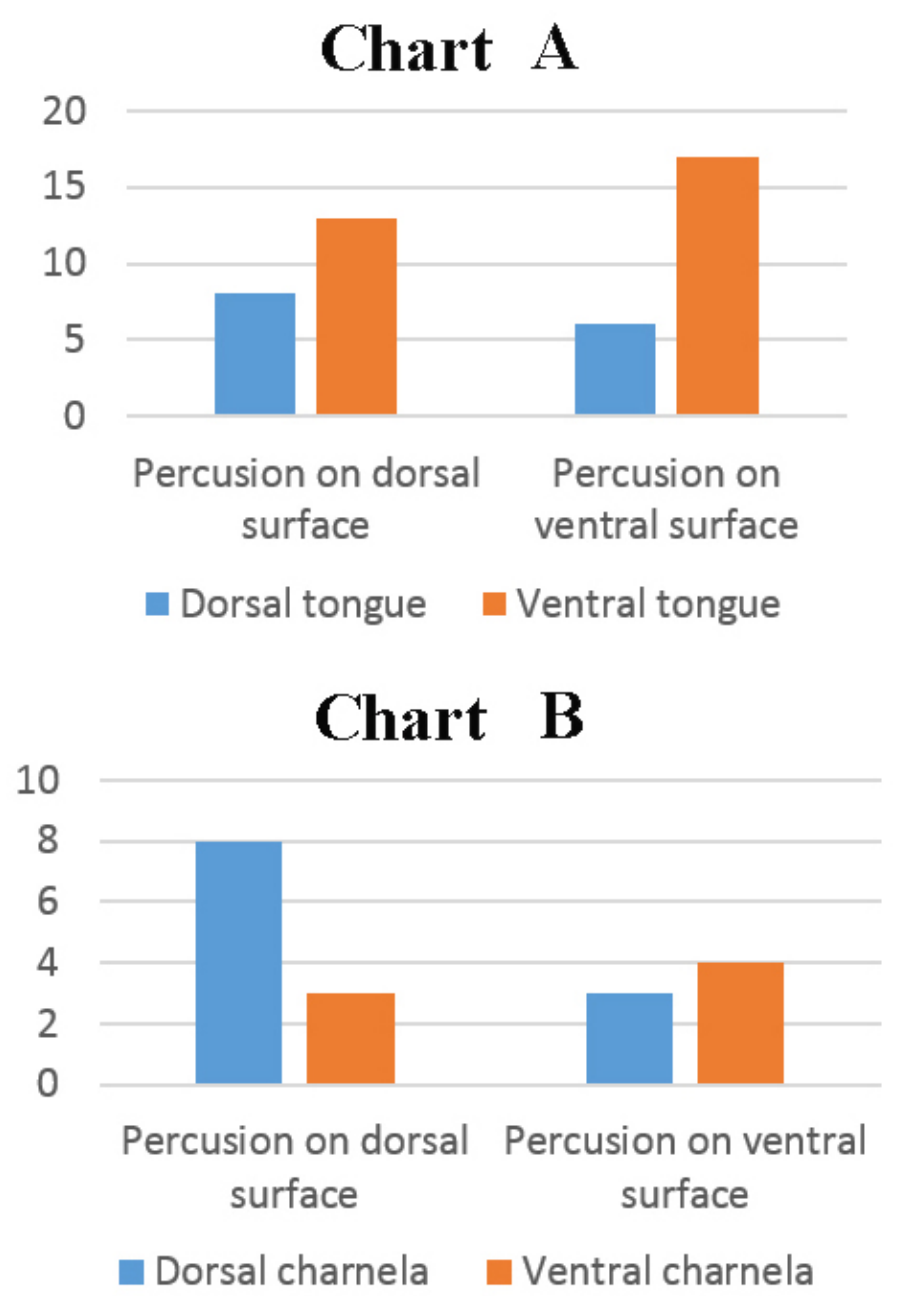

Figure 9. Chart A: tongue appearance face according to the impact face. Chart B: charnelas appearance face according to the impact face.

The absence of marks is another important aspect to highlight. Flexing has provided only one piece with two planes of fracture without marks, and during indirect percussion there are no examples without them. When referring to planes without marks, the fracturing causes have been considered indeterminate or knapping accidents by Bernaldo de Quiros et al. (1981: 18), however, in our experiments they are almost exclusively produced by direct percussion, although they only represent $17.65 \%$ of the total.

Regarding the hardness of the hammer, as with the type of fracture, it has not proven to be significant when determining the type of stigma that is produced (Table 6).

Table 6. Percentages of fracture stigma occurrences according to technique used and hardness of the hammer.

\begin{tabular}{llcccccc}
\hline Technique & Hammer & $\begin{array}{c}\text { Tongue } \\
\text { Count (\%) }\end{array}$ & $\begin{array}{c}\text { Charnela } \\
\text { Count (\%) }\end{array}$ & $\begin{array}{c}\text { Fall } \\
\text { Count (\%) }\end{array}$ & $\begin{array}{c}\text { Step } \\
\text { Count (\%) }\end{array}$ & $\begin{array}{c}\text { Bulge } \\
\text { Count (\%) }\end{array}$ & $\begin{array}{c}\text { No marks } \\
\text { Count (\%) }\end{array}$ \\
\hline Flex & & $10(35.71)$ & $3(10.71)$ & $6(21.43)$ & $4(14.29)$ & $3(10.71)$ & $2(7.14)$ \\
\hline Direct & Stone & $6(33.33)$ & $2(11.11)$ & $4(22.22)$ & $2(11.11)$ & $2(11.11)$ & $2(11.11)$ \\
percussion & Antler & $4(25.00)$ & $3(18.75)$ & 0 & $2(12.50)$ & $3(18.75)$ & $4(25.00)$ \\
& Subtotal & $\mathbf{1 0 ( 2 9 . 4 1 )}$ & $\mathbf{5 ( 1 4 . 7 1 )}$ & $\mathbf{4 ( 1 1 . 7 6 )}$ & $\mathbf{4 ( 1 1 . 7 6 )}$ & $\mathbf{5 ( 1 4 . 7 1 )}$ & $\mathbf{6 ( 1 7 . 6 5 )}$ \\
\hline Indirect & Stone & $5(31.25)$ & $4(25.00)$ & $2(12.50)$ & $2(12.50)$ & $3(18.75)$ & 0 \\
percussion & Antler & $\mathbf{8 ( 5 0 . 0 0 )}$ & 0 & $2(12.50)$ & $6(37.50)$ & 0 & 0 \\
& Subtotal & $\mathbf{1 3 ( 4 0 . 6 3 )}$ & $\mathbf{4 ( 1 2 . 5 0 )}$ & $\mathbf{4 ( 1 2 . 5 0 )}$ & $\mathbf{8 ( 2 5 . 0 0 )}$ & $\mathbf{3 ( 9 . 3 8 )}$ & $\mathbf{0}$ \\
\hline & Total: & $\mathbf{2 3 ( 3 4 . 8 5 )}$ & $\mathbf{9 ( 1 3 . 6 4 )}$ & $\mathbf{8 ( 1 2 . 1 2 )}$ & $\mathbf{1 2 ( 1 8 . 1 8 )}$ & $\mathbf{8 ( 1 2 . 1 2 )}$ & $\mathbf{6 ( 9 . 0 9 )}$ \\
\hline
\end{tabular}


The type and hardness of the supporting surface has been significant in two aspects. With the blade completely supported, falls were not generated. All negative parts of the tongues have been steps. On the other hand, only percussion with soft hammers generated fractures without marks, regardless of the way the blade was placed on the supporting element (Table 7).

Table 7. Percentages of fracture stigma occurrences according to support mode and supporting surface hardness.

\begin{tabular}{llcccccc}
\hline $\begin{array}{l}\text { Way of } \\
\text { support }\end{array}$ & $\begin{array}{l}\text { Hardness } \\
\text { of the anvil }\end{array}$ & $\begin{array}{c}\text { Tongue } \\
\text { Count (\%) }\end{array}$ & $\begin{array}{c}\text { Charnela } \\
\text { Count (\%) }\end{array}$ & $\begin{array}{c}\text { Fall } \\
\text { Count (\%) }\end{array}$ & $\begin{array}{c}\text { Step } \\
\text { Count (\%) }\end{array}$ & $\begin{array}{c}\text { Bulge } \\
\text { Count (\%) }\end{array}$ & $\begin{array}{c}\text { No marks } \\
\text { Count (\%) }\end{array}$ \\
\hline Complete & Hard & $6(37.50)$ & $2(12.50)$ & 0 & $6(37.50)$ & $2(12.50)$ & 0 \\
& Soft & $3(18.75)$ & $3(18.75)$ & 0 & $3(18.75)$ & $3(18.75)$ & $4(25.00)$ \\
& Subtotal & $\mathbf{9 ( 2 8 . 1 3 )}$ & $\mathbf{5 ( 1 5 . 6 3 )}$ & $\mathbf{0}$ & $\mathbf{9 ( 2 8 . 1 3 )}$ & $\mathbf{5 ( 1 5 . 6 3 )}$ & $\mathbf{4 ( 1 2 . 5 0 )}$ \\
\hline Semi & Hard & $7(41.18)$ & $2(11.76)$ & $6(35.29)$ & 0 & $2(11.76)$ & 0 \\
& Soft & $6(37.50)$ & $2(12.50)$ & $2(12.50)$ & $3(18.75)$ & $1(6.25)$ & $2(12.50)$ \\
& Subtotal & $\mathbf{1 3 ( 3 9 . 3 9 )}$ & $\mathbf{4 ( 1 2 . 1 2 )}$ & $\mathbf{8 ( 2 4 . 2 4 )}$ & $\mathbf{3 ( 9 . 0 9 )}$ & $\mathbf{3 ( 9 . 0 9 )}$ & $\mathbf{2 ( 6 . 0 6 )}$ \\
\hline
\end{tabular}

\section{Indirect fracture marks}

All indirect fractures have some type of stigma. As occurs with direct fractures, the stigma with highest representation is the tongue. The rest are closely matched percentages (see Table 8).

Table 8. Indirect fractures. Relation between fracture marks documented in regards to the way the blade is placed on the anvil and the hardness of the surface of support.

\begin{tabular}{llllcccc}
\hline $\begin{array}{l}\text { Way of } \\
\text { support }\end{array}$ & $\begin{array}{l}\text { Hardness } \\
\text { of the anvil }\end{array}$ & $\begin{array}{c}\text { Tongue } \\
\text { Count (\%) }\end{array}$ & $\begin{array}{c}\text { Charnela } \\
\text { Count (\%) }\end{array}$ & $\begin{array}{c}\text { Fall } \\
\text { Count (\%) }\end{array}$ & $\begin{array}{c}\text { Step } \\
\text { Count (\%) }\end{array}$ & $\begin{array}{c}\text { Bulge } \\
\text { Count (\%) }\end{array}$ & $\begin{array}{c}\text { No marks } \\
\text { Count (\%) }\end{array}$ \\
\hline Complete & Hard & $2(33.33)$ & $1(16.67)$ & 0 & $2(33.33)$ & $1(16.67)$ & 0 \\
& Soft & $3(33.33)$ & $1(11.11)$ & $2(22.22)$ & $1(11.11)$ & $2(22.22)$ & 0 \\
& Subtotal & $\mathbf{5 ( 3 3 . 3 3 )}$ & $\mathbf{2 ( 1 3 . 3 3 )}$ & $\mathbf{2 ( 1 3 . 3 3 )}$ & $\mathbf{3 ( 2 0 . 0 0 )}$ & $\mathbf{3 ( 2 0 . 0 0 )}$ & $\mathbf{0}$ \\
\hline Semi & Hard & $2(33.33)$ & $1(16.67)$ & $1(16.67)$ & $1(16.67)$ & $1(16.67)$ & 0 \\
& Soft & $3(37.50)$ & $2(25.00)$ & $2(25.00)$ & 0 & $1(12.50)$ & 0 \\
& Subtotal & $\mathbf{5 ( 3 5 . 7 1 )}$ & $\mathbf{3 ( 2 1 . 4 3 )}$ & $\mathbf{3 ( 2 1 . 4 3 )}$ & $\mathbf{1 ( 7 . 1 4 )}$ & $\mathbf{2 ( 1 4 . 2 9 )}$ & $\mathbf{0}$ \\
\hline
\end{tabular}

\section{Macro-wear}

The macro-wear documented during the experimentation has been categorized into the following types: point of impact, lateral or central flake, bulbar flake, percussion bulb, stepping, cracks, peelings, flaking, and false impact point. Nonetheless, the most relevant ones that appeared during our experimentation are explained in the following text (see Figure 10).

Macro-wear on the marks derived from the application of force during the fragmentation of the lithic element. These marks can be classified into two major groups - those where the force breaks the material, and those that create a displacement of matter by plastic deformation (see Tables 9 and 10). 

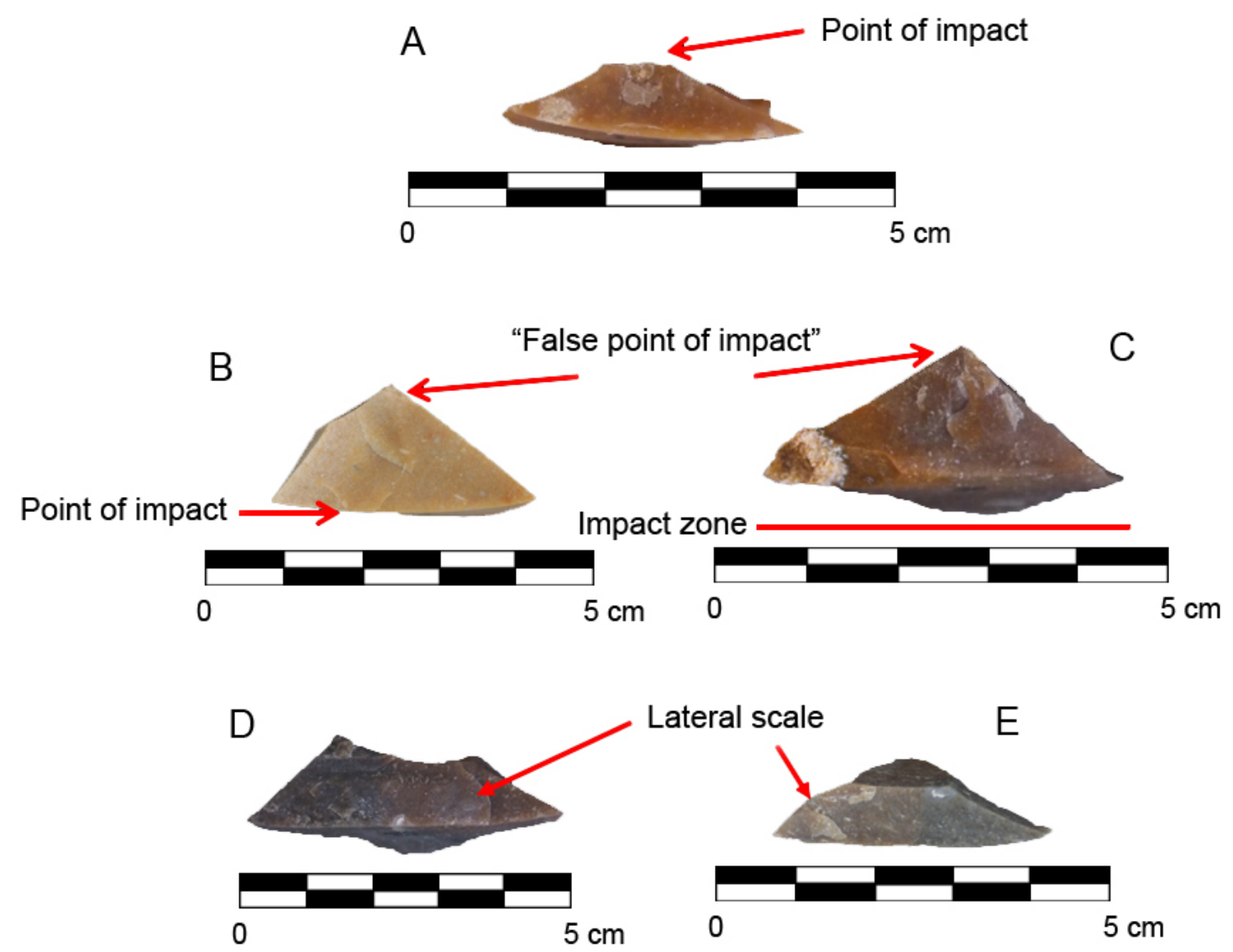

Figure 10: A: point of impact on the dorsal face; B: sample hit on the ventral face presenting a point of impact on the ventral side and a false point of impact on the dorsal face; $C$ : ventral impact only presenting a false point of impact on the edge with the dorsal face; D: central flake that begins to develop on the left side of the blade; E: lateral flake developed on the left side of the blade.

Cracks, peeling, flaking and lateral flakes are developed due to a rupture of the material. They are the most common macro-wear and are associated with all of the fragmentation techniques, as well as to direct and the indirect fractures. In the latter case they are almost the only macro-wear that appear. From observations of both types of fracturing, peelings appear in the same ratio (53.2\% and 53.3\% respectively). Regarding the remaining macro-wear types, fissures and lateral flakes are the most frequent, while peeling decreases. All of them are more common in the direct fragments. According to the techniques, the marks that appeared in samples where flexing was applied, especially from the dorsal side, must be particularly highlighted. 
Table 9. Macrowear documented on direct fractures (94). Abbreviations: * = Amount of cases documented (each * represents a case). Note: There are 94 fractures which present a total number of 185 documented signs of macrowear. A fracture can present various signs macrowear.

\begin{tabular}{|c|c|c|c|c|c|c|c|c|c|c|c|c|}
\hline Impact face & Percussion & Hammer & $\begin{array}{l}\text { Way of } \\
\text { support }\end{array}$ & $\begin{array}{l}\text { Hardness } \\
\text { of the anvil }\end{array}$ & $\begin{array}{c}\text { Impact } \\
\text { point }\end{array}$ & $\begin{array}{c}\text { False impact } \\
\text { point }\end{array}$ & Bulb & Lat. scale & Stepping & Cracks & Peeling & Flaking \\
\hline \multirow[t]{24}{*}{ Dorsal (48) } & Flex & & & & 0 & 0 & 0 & 6 & 0 & 5 & 0 & 9 \\
\hline & Subtotal: & & & & 0 & 0 & 0 & 6 & 0 & 5 & 0 & 9 \\
\hline & Direct percussion (18) & Stone & Complete & Hard & & & & $*$ & & $*$ & & $* *$ \\
\hline & & & & Soft & & $* *$ & & $*$ & & $* *$ & & $* *$ \\
\hline & & & Semi & Hard & $*$ & & $*$ & $*$ & $* *$ & $*$ & & $*$ \\
\hline & & & & Soft & & & & & & * & & \\
\hline & & Total: & & & 1 & 2 & 1 & 3 & 2 & 5 & 0 & 5 \\
\hline & & Antler & Complete & Hard & $*$ & & & & & & $*$ & * \\
\hline & & & & Soft & $* *$ & & & & & $*$ & & $* *$ \\
\hline & & & Semi & Hard & $* *$ & & & $*$ & & $*$ & & $* *$ \\
\hline & & & & Soft & $* *$ & & $* *$ & & & & & \\
\hline & & Total: & & & 7 & 0 & 2 & 1 & 0 & 2 & 1 & 5 \\
\hline & Subtotal: & & & & 8 & 2 & 3 & 4 & 2 & 7 & 1 & 10 \\
\hline & Indirect percussion (16) & Copper & Complete & Hard & $*$ & & & $* *$ & & $* *$ & $*$ & $* *$ \\
\hline & & & & Soft & & & & & & & & $* *$ \\
\hline & & & Semi & Hard & $* *$ & & & & & & & $* *$ \\
\hline & & & & Soft & $*$ & & & & & & & \\
\hline & & Total & & Total & 4 & 0 & 0 & 2 & 0 & 2 & 1 & 6 \\
\hline & & Antler & Complete & Hard & $*$ & & & $*$ & & $* *$ & & $* *$ \\
\hline & & & & Soft & & & & $*$ & & $* *$ & & $* *$ \\
\hline & & & Semi & Hard & & & & $*$ & & $*$ & & $*$ \\
\hline & & & & Soft & $*$ & & $*$ & $*$ & & & & $* *$ \\
\hline & & Total & & & 2 & 0 & 1 & 4 & 0 & 5 & 0 & 7 \\
\hline & Subtotal & & & & 6 & 0 & 1 & 6 & 0 & 7 & 1 & 13 \\
\hline Total: & & & & & 14 & 2 & 4 & 16 & 2 & 19 & 2 & 32 \\
\hline
\end{tabular}




\begin{tabular}{|c|c|c|c|c|c|c|c|c|c|c|c|c|}
\hline Impact face & Percussion & Hammer & $\begin{array}{l}\text { Way of } \\
\text { support }\end{array}$ & $\begin{array}{l}\text { Hardness } \\
\text { of the anvil }\end{array}$ & $\begin{array}{l}\text { Impact } \\
\text { point }\end{array}$ & $\begin{array}{c}\text { False impact } \\
\text { point }\end{array}$ & Bulb & Lat. scale & Stepping & Cracks & Peeling & Flaking \\
\hline \multirow[t]{24}{*}{ Ventral (46) } & Flex & & & & & & & 3 & 1 & 6 & 1 & 3 \\
\hline & Subtotal: & & & & 0 & 0 & 0 & 3 & 1 & 6 & 1 & 3 \\
\hline & Direct percussion (16) & Stone & Complete & Hard & & $* *$ & & $*$ & & $* *$ & & $* *$ \\
\hline & & & & Soft & & $* *$ & $*$ & $*$ & & $*$ & & \\
\hline & & & Semi & Hard & & & $*$ & $*$ & & $* *$ & & $* *$ \\
\hline & & & & Soft & & & & $*$ & & $*$ & & $* *$ \\
\hline & & Total: & & & 0 & 4 & 2 & 4 & 0 & 6 & 0 & 6 \\
\hline & & Antler & Complete & Hard & & $*$ & $*$ & $*$ & & & & $*$ \\
\hline & & & & Soft & & & & $*$ & & $* *$ & $*$ & $*$ \\
\hline & & & Semi & Hard & & & & & & $* *$ & $*$ & $* *$ \\
\hline & & & & Soft & & & & $*$ & & & $*$ & $*$ \\
\hline & & Total: & & & 0 & 1 & 1 & 3 & 0 & 4 & 3 & 5 \\
\hline & Subtotal: & & & & 0 & 5 & 3 & 7 & 0 & 10 & 3 & 11 \\
\hline & Indirect percussion (16) & Copper & Complete & Hard & & $*$ & $*$ & $*$ & & $* *$ & $*$ & $* *$ \\
\hline & & & & Soft & $* *$ & & $*$ & & & & & $* *$ \\
\hline & & & Semi & Hard & & & & $*$ & & $* *$ & & $* *$ \\
\hline & & & & Soft & & & & $*$ & & $* *$ & $* *$ & $* *$ \\
\hline & & Total: & & & 2 & 1 & 2 & 3 & 0 & 6 & 3 & 8 \\
\hline & & Antler & Complete & Hard & & $*$ & & & & $* *$ & $*$ & $* *$ \\
\hline & & & & Soft & $*$ & & & & & $*$ & & $* *$ \\
\hline & & & Semi & Hard & & & & & $*$ & & & $*$ \\
\hline & & & & Soft & & & & $*$ & $* *$ & & & $*$ \\
\hline & & Total: & & & 1 & 1 & 0 & 1 & 3 & 3 & 1 & 6 \\
\hline & Subtotal & & & & 3 & 2 & 2 & 4 & 3 & 9 & 4 & 14 \\
\hline Total: & & & & & 3 & 7 & 5 & 14 & 4 & 25 & 8 & 28 \\
\hline Total: & 185 & & & & 17 & 9 & 9 & 30 & 6 & 44 & 10 & 60 \\
\hline
\end{tabular}


Table 10. Macrowear documented on indirect fractures (30). Abbreviations: 0 =No macrowear documented; * = Amount of cases documented (each * represents a case); - = Does not exist indirect fracture. Note: There are 30 fractures which present a total number of 34 documented signs of macrowear. A fracture can present various signs macrowear.

\begin{tabular}{|c|c|c|c|c|c|c|c|c|c|c|c|c|}
\hline Impact face & Percussion & Hammer & $\begin{array}{l}\text { Way of } \\
\text { support }\end{array}$ & $\begin{array}{l}\text { Hardness } \\
\text { of the anvil }\end{array}$ & $\begin{array}{c}\text { Impact } \\
\text { point }\end{array}$ & $\begin{array}{c}\text { False impact } \\
\text { point }\end{array}$ & Bulb & Lat. scale & Stepping & Cracks & Peeling & Flaking \\
\hline \multirow[t]{22}{*}{ Dorsal (16) } & Direct percussion (8) & Stone & Complete & Hard & 0 & 0 & 0 & 0 & 0 & $*$ & 0 & 0 \\
\hline & & & & Soft & 0 & 0 & 0 & 0 & 0 & 0 & 0 & 0 \\
\hline & & & Semi & Hard & - & - & - & - & - & - & - & - \\
\hline & & & & Soft & - & - & - & - & - & - & - & - \\
\hline & & Total: & & & & & & & & 1 & & \\
\hline & & Antler & Complete & Hard & - & - & - & - & - & - & - & - \\
\hline & & & & Soft & 0 & 0 & 0 & 0 & 0 & 0 & 0 & $* *$ \\
\hline & & & Semi & Hard & - & - & - & - & - & - & - & - \\
\hline & & & & Soft & 0 & 0 & 0 & 0 & 0 & $* *$ & 0 & 0 \\
\hline & & Total: & & & 0 & 0 & 0 & 0 & 0 & 2 & 0 & 2 \\
\hline & Subtotal: & & & & 0 & 0 & 0 & 0 & 0 & 3 & 0 & 2 \\
\hline & Indirect percussion (8) & Copper & Complete & Hard & 0 & 0 & 0 & 0 & 0 & 0 & 0 & $* *$ \\
\hline & & & & Soft & 0 & 0 & 0 & 0 & $*$ & $*$ & 0 & $*$ \\
\hline & & & Semi & Hard & - & - & - & - & - & - & - & - \\
\hline & & & & Soft & - & - & - & - & - & - & - & - \\
\hline & & Total & & & 0 & 0 & 0 & 0 & 1 & 1 & 0 & 3 \\
\hline & & Antler & Complete & Hard & - & - & - & - & - & - & - & - \\
\hline & & & & Soft & 0 & 0 & 0 & $* *$ & 0 & $*$ & 0 & 0 \\
\hline & & & Semi & Hard & - & - & - & - & - & - & - & - \\
\hline & & & & Soft & 0 & 0 & 0 & 0 & 0 & $* *$ & 0 & $* *$ \\
\hline & & Total & & & 0 & 0 & 0 & 2 & 0 & 3 & 0 & 2 \\
\hline & Subtotal & & & & 0 & 0 & 0 & 2 & 1 & 4 & 0 & 5 \\
\hline Total: & & & & & 0 & 0 & 0 & 2 & 1 & 7 & 0 & 7 \\
\hline
\end{tabular}




\begin{tabular}{|c|c|c|c|c|c|c|c|c|c|c|c|c|}
\hline Impact face & Percussion & Hammer & $\begin{array}{l}\text { Way of } \\
\text { support }\end{array}$ & $\begin{array}{l}\text { Hardness } \\
\text { of the anvil }\end{array}$ & $\begin{array}{c}\text { Impact } \\
\text { point }\end{array}$ & $\begin{array}{c}\text { False impact } \\
\text { point }\end{array}$ & Bulb & Lat. scale & Stepping & Cracks & Peeling & Flaking \\
\hline \multirow[t]{22}{*}{ Ventral (14) } & Direct percussion (2) & Stone & Complete & Hard & - & - & - & - & - & - & - & - \\
\hline & & & & Soft & - & - & - & - & - & - & - & - \\
\hline & & & Semi & Hard & - & - & - & - & - & - & - & - \\
\hline & & & & Soft & - & - & - & - & - & - & - & - \\
\hline & & Total: & & & - & - & - & - & - & - & - & - \\
\hline & & Antler & Complete & Hard & 0 & 0 & 0 & $*$ & 0 & 0 & 0 & $*$ \\
\hline & & & & Soft & - & - & - & - & - & - & - & - \\
\hline & & & Semi & Hard & - & - & - & - & - & - & - & - \\
\hline & & & & Soft & - & - & - & - & - & - & - & - \\
\hline & & Total: & & & 0 & 0 & 0 & 1 & 0 & 0 & 0 & 1 \\
\hline & Subtotal: & & & & 0 & 0 & 0 & 1 & 0 & 0 & 0 & 1 \\
\hline & Indirect percussion (12) & Copper & Complete & Hard & - & - & - & - & - & - & - & - \\
\hline & & & & Soft & - & - & - & - & - & - & - & - \\
\hline & & & Semi & Hard & 0 & 0 & 0 & $*$ & 0 & $*$ & 0 & $* *$ \\
\hline & & & & Soft & 0 & 0 & 0 & $*$ & 0 & $*$ & $*$ & $*$ \\
\hline & & Total: & & & 0 & 0 & 0 & 2 & 0 & 2 & 1 & 3 \\
\hline & & Antler & Complete & Hard & - & - & - & - & - & - & - & - \\
\hline & & & & Soft & 0 & 0 & 0 & 0 & 0 & 0 & 0 & $* *$ \\
\hline & & & Semi & Hard & 0 & 0 & 0 & 0 & 0 & 0 & 0 & $* *$ \\
\hline & & & & Soft & 0 & 0 & 0 & $*$ & 0 & $*$ & 0 & $*$ \\
\hline & & Total: & & & 0 & 0 & 0 & 1 & 0 & 1 & 0 & 5 \\
\hline & Subtotal & & & & 0 & 0 & 0 & 3 & 0 & 3 & 1 & 8 \\
\hline Total: & & & & & 0 & 0 & 0 & 4 & 0 & 3 & 1 & 9 \\
\hline Total: & 34 & & & & 0 & 0 & 0 & 6 & 1 & 10 & 1 & 16 \\
\hline
\end{tabular}




\section{Conclusions}

In conclusion, from the Late Neolithic, a new concept applied to the creation of lithic tools arose, involving the fracturing of blades through the improvement of fracturing techniques. In addition, a preference for obtaining the mesial fragments of the blades or those which have more regular measurements can be observed.

The preliminary study through this experimentation has made it possible to define and describe the types of fractures resulting from the use of different blade fracturing methods. We also have described the main types of fracture marks generated from each fracturing technique. Therefore, for example, radial and cone fractures are indicative of percussion, the latter being generated exclusively through indirect percussion. On the other hand, simple fractures present a higher percentage when using direct percussion and flexing. Finally, flat planes are associated preferentially with simple fractures and irregular planes with radial or cone fractures.

As for the fracture marks, it was found that the tongue is the most abundant, regardless of the technique used. However, if the objective involves obtaining fractures without accidents, in thicker blades, where flexing cannot be used, only direct percussion can generate this type of fracture.

The hardness of the hammer was not significant, neither in determining the type of fracture nor the marks. In the case of percussion, the way of supporting the blades and the face where the force is applied are fundamental for the generation of indirect fractures, since there are more indirect fractures when blades are completely supported and are impacted on the dorsal side. On the other hand, these are more abundant with partially supported blades and when hit on the ventral surface. However, in this regard, the distal curvature and the regularity of the thickness of the blade play a significant part.

When analysing the macro-wear, the presence of certain types is very common, especially flaking, as well as cracks and lateral flakes. Considering macro-wear associated with force displacement (point of impact, bulb, and stepping) one can conclude that they are not associated with flexing, nor with indirect fragments obtained by percussion. It should be noted that the point of impact is not indicative of the impact area, as is evidenced by the existence of numerous false impact points generated by backlash on the anvil.

Other aspects that may influence the generation of certain types of fractures or marks must be taken into account with regard to future experiments, as are, for example, the section of the blade and the type of raw material. Furthermore, a study regarding fractures resulting from many different causes such as those generated accidentally during knapping, trampling, accidental falls and post-depositional processes, must be carried out, and it is hoped that they can be include in future research.

Finally, other research lines include the use of these fractured and bi-fractured blades, especially of mesial parts, either retouched or unretouched, for example, the specific functionality of some of these objects related to agricultural activities, noted by the presence of cereal polish.

\section{References}

Armendariz Martija, J. \& Irigaray Soto, S. 1992, Aportación al estudio de los yacimientos líticos postpaleolíticos al aire libre de Navarra. Zephyrus, 44-45(1991-1992): 223-240. (in Spanish) ("Contribution to the study of post-Palaeolithic lithic sites in the open air of Navarra”) URL: http://revistas.usal.es/index.php/0514-7336/article/view/3373 
Aschero, C.A. (1975), Ensayo para una clasificación morfológica de artefactos líticos aplicada a estudios tipológicos comparativos. Unpublished manuscript in the library of the Instituto de Arqueología, FFyL-UBA, Report presented to the National Council of Scientific and Technical Research (CONICET), Buenos Aires. Argentina, Buenos Aires. (in Spanish) ("Test for a morphological classification of lithic artifacts applied to comparative typological studies") (Not consulted by the authors. This reference is mentioned in another paper and was considered of potential relevance.)

Bernaldo de Quirós, F.; Cabrera, V.; Cacho, C. Vega, L.G. 1981, Proyecto de análisis técnico para las industrias líticas. Trabajos de Prehistoria 38(1): 9-38. (in Spanish) (“Technical analysis project for the lithic industries”)

URL: https://dialnet.unirioja.es/servlet/articulo?codigo=257734

Crabtree, D. E. 1972, An Introduction to Flint working. Occasional Papers of the Idaho State University Museum Vol. 28, Idaho State University Museum, Pocatello, 98 p.

Chapman, J. 2001, Object Fragmentation in the Neolithic and Copper Age of Southeast Europe. In: The Archaeology of Cult and Religion (Biehl, P. F., Bertemes, F. \& Meller, H., Eds.), Archaeolingua, Budapest: p. 89-106.

Deller, B. D., \& Ellis, C. J. 2001, Evidence for late Paleoindian ritual from the Caradoc site (AfHj-104), southwestern Ontario, Canada. American Antiquity, 66(2): 267-284. doi:10.2307/2694608

Flegenheimer, N.; \& Weitzel, C. 2007, Caminar sobre piedras: los artefactos fracturados de Cerro El Sombrero. Comechingonia Virtual, Actas del XVI Congreso Nacional de Arqueología Argentina, 3: p. 263-267. (in Spanish) ("Walking on stones: the fractured artifacts of Cerro El Sombrero")

Flores Fernández, R. 2011, El yacimiento de Humanejos, Parla, Madrid. In: Yacimientos con campaniforme de la región de Madrid. Nuevos estudios (Blasco, C., Liseau, C., \& Ríos, P., Eds.), Universidad Autónoma de Madrid, Madrid: p. 9-16. (in Spanish) ("The Humanejos deposit, Parla, Madrid”)

Flores Fernández, R., \& Garrido Pena, R. 2012, Campaniforme y conflicto social: Evidencias del yacimiento de Humanejos (Parla, Madrid). In: Actas de las novenas jornadas de Patrimonio Arqueológico en la Comunidad de Madrid. Comunidad de Madrid, Consejería de Cultura y Deportes. Dirección General de Patrimonio Histórico, Madrid: p. 159-168. (in Spanish) ("Campaniform and social conflict: Evidence from the Humanejos deposit (Parla, Madrid)”)

URL: https://dialnet.unirioja.es/servlet/articulo?codigo=6066685

Fortea Pérez, J.; Martí Oliver, \& C.; Cabanilles, J.J. 1985, La industria lítica tallada del Neolítico Antiguo en la vertiente Mediterránea de la Península ibérica. In: Chipped Stone Industries of the Early Farming Cultures in Europe (papers delivered on the International Symposium). Archaeologia Interregionalis Vol. 9, Wydawn Uniwersytetu Warszawskiego, Warsaw: p. 7-22. (in Spanish) ("The groundstone lithic industry from the Early Neolithic on the Mediterranean side of the Iberian Peninsula”)

Frison, G. C., \& Bradley, B. 1980, Folsom tool and technology at the Hanson Site, Wyoming. University of New Mexico Press, Albuquerque, 135 p. 
Gallet, M. 1998, Pour une technologie des débitages laminaires préhistoriques. Dosier de documentation archéologique Vol. 19, (Reprinted in 2002), Centre National de La Recherche Scientifique (CNRS), Paris, 180 p. (in French) ("For a technology of prehistoric laminar debitage")

Gallet, M, \& Texier, P.J. 1991, Caracterisation et evaluation des contraintes lors d'un débitage experimental de lames par pression, Perspectives experimentales et implications archéologiques. In: La pierre préhistorique (Menu, M., \& Walter, P., Eds.), Laboratoire de recherche des musées de France, París: p. 127-132. (in French) (“Characterization and stress evaluation during experimental blade débitage by pressure, Experimental perspectives and archaeological implications”)

Gutiérrez Sáez, C. 1998, Aportaciones al estudio de la industria lítica a la comprensión del fenómeno calcolítico. Yacimiento de Llanete de los Moros (Montoro, Córdoba).

Espacio, Tiempo y Forma, Serie I, Prehistoria y Arqueología, 11: 191-210. (in Spanish)

("Contributions to the study of the lithic industry to the understanding of the Chalcolithic phenomenon. Deposit of Llanete de los Moros (Montoro, Córdoba)”) URL: http://revistas.uned.es/index.php/ETFI/article/view/4673

Inizan, M.L. Roche. H., \& Tixier, J. 1992, Technology of Knapped Stone. Préhistorie de la Pierre Taillée Vol. 3. Cercle de Recherches et d’Etudes Préhistoriques, Meudon, 127 p.

Jennings, T. A. 2011, Experimental production of bending and radial flake fractures and implications for lithic technologies. Journal of Archaeological Science, 38(12): 36443651. doi:10.1016/j.jas.2011.08.035

Lintz, C., \& Dockall, J. 2002, The spreen cache: A case study of a prehistoric curated collection of broken tools from 41RN108, Runnels county, Texas. Lithic Technology, 27(1): 13-37. doi:10.1080/01977261.2002.11720987

Miller, M. J. 2006, An experimental study of lithic biface manufacture: Toward understanding the perverse fracture. Master of Arts dissertation paper, Unpublished Master's thesis, University of Exeter, Exeter. (Not consulted by the authors. This reference is mentioned in another paper and was considered of potential relevance.)

Pelegrin, J. 2000, Les techniques de débitage laminaire au Tardiglaciaire: critères de diagnose et quelques ré e- xions. In: L'Europe centrale et septentrionale auTardiglaciaire: confrontation des modèles régionaux de peuplement. Actes de la Table ronde internationale de Nemours, 14-16 mai 1997. (Valentin, B., Bodu P., \& Christensen, M., Eds.), Mémoires du Musée de Préhistoire d’Ile de France Vol. 7, Association pour la promotion de la recherche archéologique en Ile-de-France (APRAIF), Nemours: p. 7385. (in French) ("Laminar debitage techniques at the Late Glacial: diagnostic criteria and some revisions")

Pelegrin, J. 2012, New Experimental Observations for the Characterization of Pressure Blade Production Techniques. In: The Emergence of Pressure Knapping: From Origin to Modern Experimentation (Desrosiers, P. \& Rhamani, N., Eds.), Springer Editions, Bston: p. 465-500. 
Pelegrin, J., \& Morgado, A. 2007, Primeras experimentaciones sobre la producción laminar del Neolítico Reciente-Edad del Cobre del sur de la Península Ibérica. In: Arqueología Experimental en la Península Ibérica: investigación, didáctica y patrimonio (Ramos Sáinz, M.L., González Urquijo, J.E., \& Baena Preysler, J., Eds.), Asociación Española de Arqueología Experimental, Santander, Spain: p. 131-139. (in Spanish) (“First experiments on the laminar production of the Recent Neolithic - Copper Age of the south of the Iberian Peninsula")

Ramos Muñoz, J. 1989, Las industrias líticas del Neolítico en Andalucía, sus implicaciones espaciales y económicas, Zephyrus: Revista de prehistoria y arqueología, 41-42: 113148.

Ramos Muñoz, J. 1992, La industria lítica del Cobre Pleno del poblado de Valencia de la Concepción (Sevilla). Norba, Revista de Historia, 11-12: 43-74. (in Spanish) ("The lithic industry of the Cobre Pleno of the town of Valencia de la Concepción (Seville)") URL: https://dialnet.unirioja.es/servlet/articulo?codigo=109873

Weitzel, C. 2010, Una propuesta analítica y clasificatoria para las fracturas en artefactos líticos formatizados por talla. In: Arqueología Argentina en el Bicentenario de la Revolución de Mayo, Vol. 1 (Bárcena, J.R. \& Chiavazza, H., Eds.), Congreso Nacional de Arqueología Argentina Vol. 17, Instituto de Ciencias Humanas, Sociales y Ambientales (INCIHUSA), Buenos Aires: p. 91-96. (in Spanish) (“An analytical and classificatory proposal for fractures in lithic artifacts formatted by size”)

Weitzel, C. 2011, Rotura intencional de artefactos líticos formatizados en la Región Pampeana bonaerense. Revista del Museo de Antropología, 4: 47-64. (in Spanish) ("Intentional breakage of lithic artifacts formatted in the Pompean Region of Buenos Aires”) URL: https://revistas.unc.edu.ar/index.php/antropologia/article/view/5494

Weitzel, C. 2012, Cuentan los fragmentos: Clasificación y causas de fractura de artefactos formatizados por talla. Intersecciones en antropología, 13(1): 43-55. (in Spanish) ("Count the fragments: Classification and causes of fracture of artifacts formatted by size”) URL: http://www.scielo.org.ar/scielo.php?script=sci_arttext\&pid=S1850373X2012000100003

Weitzel, C. \& Colombo, M. 2006, ¿Qué hacemos con los fragmentos? Un experimento en fractura de artefactos líticos tallados. La Zaranda de Ideas. Revista de Jóvenes Investigadores en Arqueología, 2: 19-33. (in Spanish) ("What do we do with the fragments? An experiment in fracturing carved lithic artifacts”)

Weitzel, C., \& Flegenheimer, N. 2007, Cerro el sombrero, Argentina: Fractured stones on a flat hilltop. Current Research in the Pleistocene, 24: 68-70.

Weitzel, C., Borrazzo, K., Ceraso, A. \& Balirán, C. 2014, Trampling fragmentation potential of lithic artifacts: An experimental approach. Intersecciones En Antropología, 15: 97110. URL: http://www.scielo.org.ar/scielo.php?script=sci_arttext\&pid=S1850373X2014000300009

Whittaker, J. C. 1995, Flintknapping. making and understanding stone tools, University of Texas Press, Austin, 341 p. 